\title{
Destination bonding: Hybrid cognition using Instagram
}

\author{
Arup Kumar Baksi*
}

Assistant Professor, Department of Business Administration, Bengal Institute of Technology \& Management, Santinketan, West Bengal, India

\section{H R O N I C L E}

\section{Article history:}

Received August 28, 2015

Received in revised format

November 28, 2015

Accepted December 1, 2015

Available online

December 1, 2015

Keywords:

Destination-bonding

Cognition

Hybrid

Visitors

Instagram

Behavioural-pattern

\begin{abstract}
A B S T R A C T
Empirical research has identified the phenomenon of destination bonding as a result of summated physical and emotional values associated with the destination. Physical values, namely natural landscape \& other physical settings and emotional values, namely the enculturation processes, have a significant role to play in portraying visitors' cognitive framework for destination preference. The physical values seemed to be the stimulator for bonding that embodies action or behavior tendencies in imagery. The emotional values were the conditions that lead to affective bonding and are reflected in attitudes for a place which were evident in text narratives. Social networking on virtual platforms offers the scope for hybrid cognitive expression using imagery and text to the visitors. Instagram has emerged as an application-window to capture these hybrid cognitions of visitors. This study focuses on assessing the relationship between hybrid cognition of visitors expressed via Instagram and their bond with the destination. Further to this, the study attempts to examine the impact of hybrid cognition of visitors on the behavioral pattern of prospective visitors to the destination. The study revealed that sharing of visual imageries and related text by the visitors is an expression of the physico-emotional bonding with the destination. It was further established that hybrid cognition strongly asserts destination bonding and has been also found to have moderating impact on the link between destination bonding and electronic-word-of-mouth.
\end{abstract}

\section{Introduction}

Destination bonding has been conceptualized as a multi-dimensional construct comprising of both physical and emotional attachment of the visitors to their destination (Ramkissoon et al., 2013; Halpenny, 2010). On account of interaction between varying layers of human cognition while manifesting destination bonding, a single comprehensive organizational model explaining the same as remained elusive. Scannell and Gifford (2010) explained destination bonding with a tripartite model with 'person', 'process' and 'place' as dimensions of triangulation. While 'person' referred to the 
visitors, 'process' and 'place' referred to the complex interaction between human cognition and destination attributes resulting in behavioral outcomes. Positive outcomes depicting the love for destination have been coined as 'topophillia' (Tuan, 1974). Some environmental psychologists proposed the concept of 'schema' (Fullilove, 1996) to explain the process of alignment of beliefs and attitudes related to destination. There has been a paradigmatic shift in expression and sharing of destination experience with the advent of social networking platforms and mobile applications. Destination bonding, as an expression of hedonic and utilitarian feelings associated with the experience derived out of visiting a specific destination, is now being portrayed electronically on digital canvas. Mobile applications, namely Instagram, are gradually becoming ubiquitous and visitors are keen to share imagery and thereby generate social data. Data collected over 2012-2014 clearly indicates that usage of Instagram has been doubled (percentage-wise) confirming its proliferative impact on human cognition (Fig.1).

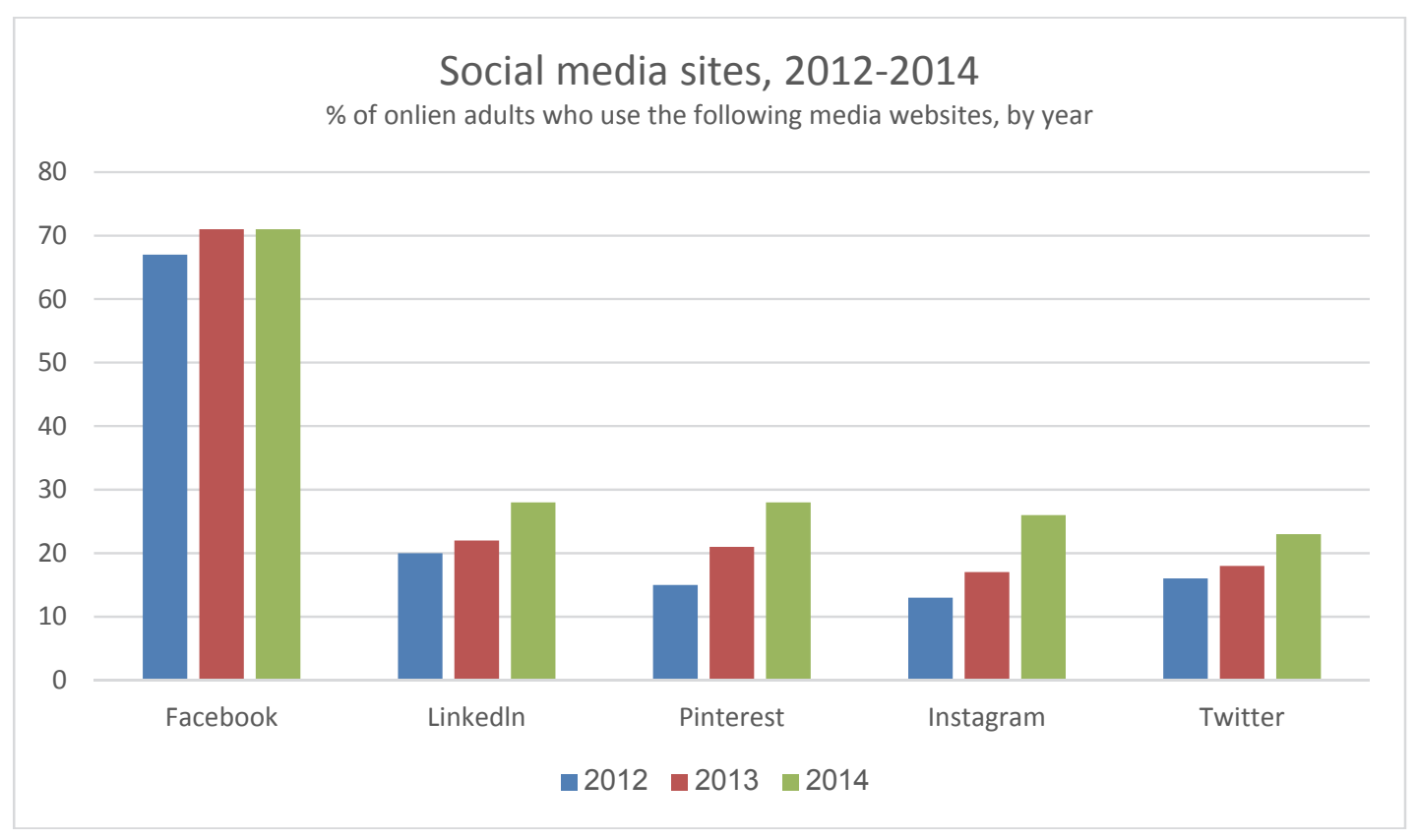

Fig. 1. Increase in use of Instagram

(Source: Pew Research Centre's Internet Project Surveys, 2012-2014, Retrieved from: http://www.pewinternet.org/2015/01/09/social-media-update-2014)

Most recent academic pool has delved into the domain of 'digital humanities' using cultural analytic techniques and identified a spatio-temporal phenomenon termed as 'visual rhythm' while explaining the capture and display of Instagram images on social networking sites (Hochman and Schwartz, 2012). Destination marketing organizations (DMOs) are gradually realizing that the user-habit related to online community alignment must be understood to offer services to prospective visitors that will act as differentials while compared against the travel portals (Xiang and Pan, 2011). The user generated content as emerged as one of the most credible sources of travel information (Xiang and Gretzel, 2010).

\section{Review of literature}

Research on destination bonding has gained momentum with the convergence of assorted disciplines namely environmental psychology, tourism, energy studies, social dislocations etc. towards understanding the issues involved in visitor-destination relationship (Halpenny, 2010; Raymond et al., 2011). Emerging focus on the phenomenon of destination bonding and its potential impact on the behavioral pattern of the visitors has been presumed by the researchers to bear significant socioeconomic connotations (Amsden et al., 2011; Su et al., 2014; Kyle et al., 2005; Marles \& Watkin, 2003) 
as a result of which a considerable stream of research flow has been witnessed in quantifying 'destination-bonding' with measured and validated scale (Kyle et al., 2005; Lee, 2011). Empirical studies have identified specific dimensions of destination bonding namely destination identity (Ramkissoon et al., 2013; Prayag \& Ryan, 2012; Line \& Costen, 2011; Hinds \& Sparks, 2008), affective attachment (Kyle et al., 2004; Lee et al., 2007; Hinds \& Sparks, 2008; Kals et al., 1999), destination dependence (Ramkissoon et al., 2013; Prayag \& Ryan, 2012; Lee et al., 2007) and social bonding (Ramkissoon et al., 2012; Hammit et al., 2006). Destination-bonding has been researched as a precursor to destination loyalty (Su et al., 2010) and they seem to be correlated (Toyama \& Yamada, 2012). According to Lewicka (2011), the intensity of destination bonding varies with the levels of cognitive loyalty starting with destination belongingness to the extreme exhibition of destination commitment. Albert and Merunka's (2013) opinion about consumer commitment and long-term association with a brand has been studied by Knez (2005) in the context of tourism and stated that destination commitment, the strongest expression of loyalty to destination, can eventually consolidate destinationvisitor bonding. Researchers predicted that while functional or tangible benefits accrued from travel experience tend to mould the cognitive self of the visitors (Brocato, 2006), affective or emotional attachment goes beyond the level of cognition (Pearce \& Lee, 2005; Riley, 1992) and spreads over a wide array of attitudes towards the destination.

Physical bonding with the destination develops on the premise of tangible and observable characters having functional values namely convenience and accessibility, perceived cost, perceived safety and security, climate and natural backdrop, dining facilities etc. (Bowen \& Clarke, 2009). Emotional bonding develops as social interaction between the visitors and local community increases (Trauer \& Ryan, 2004) resulting in favorable emotional experiences (Greider \& Garkovich, 1994) on the basis of shared culture and tradition. While predicting destination bonding, researchers were also of the opinion that 'time' (duration of stay) can be an effective predictor (Hernandez et al., 2007) and longer duration of stay may strengthen the bonding of the visitors with the destination. Travel motives play significant antecedent role to destination bonding and often it follows the Maslowian hierarchy of needs (Trauer \& Ryan, 2004). But critical cognitive hybridization of needs and desires seem to be the determining factor about the nature and intensity of visitor-destination bonding. Hybridization of travel motives is reflected as both hedonic and utilitarian drives control destination selection and frequency of visit (Yuksel et al., 2010; Bowen \& Clarke, 2009). The pool of values involved in formation of this hybrid cognition can be assigned to two major categories on the basis of research outcomes: (a) physical values and (b) emotional values (presented in tabulated form in Table 1):

Table 1

Physical and emotional values

\begin{tabular}{cc}
\hline Values and travel motives & Research evidence \\
\hline Physical values (hedonic drives) & \\
\hline $\begin{array}{c}\text { Landscape, natural beauty, climate, environmental } \\
\text { specialty, biodiversity etc. }\end{array}$ & $\begin{array}{c}\text { Ramkissoon et al., 2013; Line \& Costen, } \\
\text { 2011; Hwang et al., 2005; Raymond et } \\
\text { al., 2011; Vaske \& Kobrin, 2001 }\end{array}$ \\
$\begin{array}{cc}\text { Logistics and infrastructural support available, socio- } \\
\text { economic environment }\end{array}$ & Bowen \& Clarke, 2009; \\
\hline Emotional values (utilitarian drives) & Del Bosque \& Martin, 2008 \\
\hline Prestige and personal desires associated with the visit & Kruger \& Saayman, 2010 \\
Novelty of the destination & Smith, 2003 \\
\hline
\end{tabular}

The deep level of destination bonding based on emotional values can be attributed to human-love relationships (Hammock and Richardson, 2011). Love and passion were considered as critical relational constructs while explaining theory of bonding (Loureiro et al., 2012). 'Lovemark', considered as generation-next-theory in explaining deep bondage between human beings and 
products/brands/services/entity, evokes a sense of 'loyalty beyond rationality' (Roberts, 2004; Pawle \& Cooper, 2006) and is characterized by sensuality, intimacy and mystery (Pawle \& Cooper, 2006). Linking objects with people and its subsequent visual representation has been a part of social construction (Sayers \& Monin, 2007) which reinforces the exhibition of 'lovemark' to a destination by visual imagery.

The advent and proliferation of 'social networking' has brought a brand new canvas for the visitors where they can portray their lovemark for the destination by posting visual images captured in various format via a number of applications. According to Lin and Lu (2011) and Parra-Lopez et al. (2011), the display of images and texts on virtual platforms by the visitors, while sharing their travel experience and memories, satisfy their hedonic as well as utilitarian needs. Researchers, namely, Blackshaw and Nazzaro (2004), Mangould and Fauld (2009) coined the term 'consumer-generated media' while explaining the intricacies of social networks which offered the visitors to share the digital reproduction of their experience related to the destinations visited that can have amplifying effects in viral forms, thereby, advocating pro-destination attitudes for the prospective visitors (San Martin and Rodriguez, 2008). Changes in paradigm of physical and emotional values associated with sharing of experience of visiting destinations have witnessed visitors claiming more control over their media consumption which is reflected in on-demand access to information via shared imagery and texts (Rashtchy et al., 2007; Vollmer \& Precourt, 2008). Instagram has been one of the emerging social network platforms and mobile applications which has, on an average, 75 million active users per day with billions of usergenerated-content (UGC) in the form of images and videos (Hanan \& Putit, 2014; theverge.com, 2013). Instagram provides the unique advantage of categorizing content on the basis of a digital hashtag and filter and can be shared across more versatile network platforms namely Facebook and Twitter (Tussyadiah \& Fesenmaier, 2009; Boley et al., 2013, Criswell \& Canty, 2014). Behavioural explanation of using social medias as windows of communication has been attributed to reinforcement of 'social presence' through 'self-presentation' and 'self-disclosure' (Kaplan \& Haenlein, 2010). Content communities, namely You Tube, social networking sites namely Facebook, Linkedin and individual blogging has assumed major role towards enabling electronic-word-of-mouth (e-WOM) not only on the basis of textual content but also with explicit images and videos (Kaplan \& Haenlein, 2010).

Assimilation of physical and emotional values towards generating an attachment or bonding with a destination has, of late, been the focal research area (Criswell \& Canty, 2014; Albert \& Merunka, 2013; Ramkissoon et al., 2013; Hammock \& Richardson, 2011) stimulating the researcher to conceptualize 'hybrid cognition' as a determinant of destination bonding and its exhibition through visual imagery. This area of research is a novel one as hybrid cognition has never been test for moderation between destination bonding and e-WOM.

\subsection{Objectives of the study}

The objectives of the study are two-fold:

(a) to assess the relationship between hybrid cognition expressed by visitors through image capture and sharing by using Instagram application over versatile social network platform namely facebook and destination bonding.

(b) to examine the intervening effects, if any, of hybrid cognition on the relationship between destination bonding and behavioral intent of visitors namely electronic word-of-mouth (eWOM).

\subsection{Formulation of hypotheses}

Drawing cues from the literature reviewed and synchronizing them with the focal objectives of the study, the researcher formulates the following hypotheses for empirical testing: 
(a) $\mathrm{H}_{1}$ : There is a relationship between hybrid cognition and destination bonding.

(b) $\mathrm{H}_{01}$ : Hybrid cognition does not share any relationship with destination bonding.

(c) $\mathrm{H}_{2}$ : Hybrid cognition intervenes in the relationship between destination bonding and e-WOM

(d) $\mathrm{H}_{02}$ : Hybrid cognition does not intervene in the relationship between destination bonding and e-WOM

\subsection{Conceptual model}

The following conceptual/default model (Fig.1) was considered for empirical test:

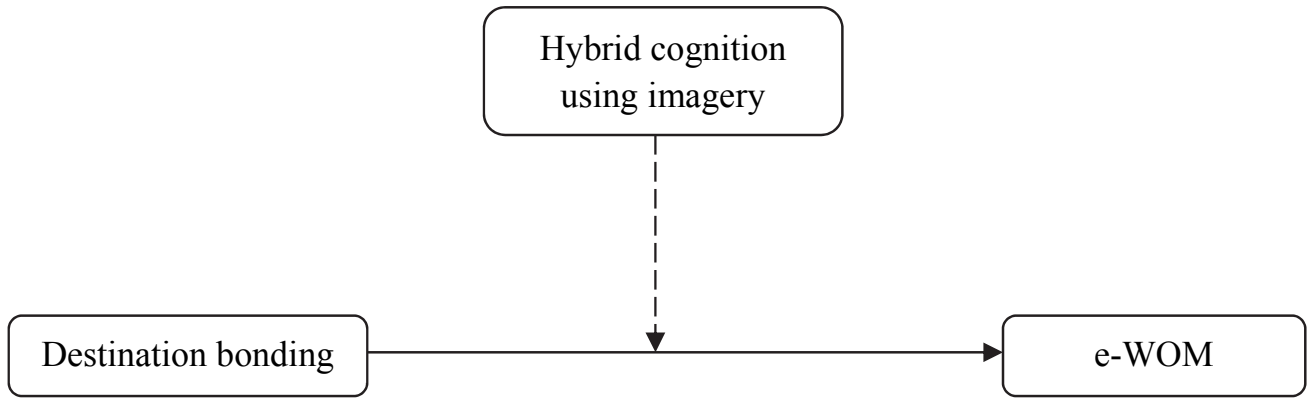

Fig.1. Conceptual/ default model for the study

\section{Methodology}

The study was a combination of qualitative and quantitative approach. While qualitative research approach was deployed to understand the deep sense of destination bonding (based on a mix of physical and emotional values) expressed by sharing of imagery and text using Instagram application by the visitors across social network platform (Facebook); quantitative research consolidated the dimensions of destination bonding and hybrid-cognition (expressed via imagery and text on Instagram application) and their relevant impacts and relationship. Quantitative research was further used to understand the intervening effects of hybrid cognition on the relationship between destination bonding and behavioural pattern of visitors. Netnography technique as suggested by Kozinets (2002) was used to obtain data from the online community using social network platform (Facebook) to share Instagram imagery and texts. Prior permissions were obtained from the informants who shared imagery and text using Instagram depicting their experience of visiting Santiniketan, a culturally and ethnically enriched destination with sheer heritage, in the state of West Bengal, India. The same informants were interviewed to have an understanding about their bondage with the destination, their hybrid cognition level (physical and emotional values associated with display of imagery using Instagram) and their future behavioural intention (electronic word-of-mouth and repeat visitation). Inevitably, convenience sampling was used with relatively small sample size. The initial Instagram imagery about Santiniketan was obtained from 145 informants sharing the same over Facebook. The electronic interview had two parts. The first part was subjective in nature and was focused on understanding the cognitive involvement of the informant while sharing Instagram images with hashtags on Facebook. The informants were asked to share their broad experience and opinion about the destination and its attributes namely (a) destination distinctiveness (destination identity), (b) destination referent continuity (coherent experience based on past visits) and destination congruent continuity (congruence with present belief about destinations preferred to visit) and (c) destination-related self esteem (feelgood or feel-proud factor). The second part of the electronic-survey was accomplished using a structured questionnaire which was mailed to each and every informant whose Instagram imagery was used for the study. The questionnaire contained scaled (7 point Likert scale) items to have an understanding about the dimensionalities of destination bonding; hybrid cognition based on imagery and a specific behavioral pattern namely electronic-word-of-moth (e-WOM). 140 complete responses were obtained. 


\subsection{Factor constructs measurement}

To measure the respondents' destination bonding, 24 items were adapted from Brown et al. (2015), Ramkissoon et al. (2013), Lee et al. (2012) and Kyle et al. (2004). Hybrid cognition using imagery has been introduced as a novel concept and did not have any specific legacy of research. e-WOM was measured using insights from the studies made by Bronner and de Hoog (2011), Volo (2010) and Dippelreiter et al., (2008). The researcher decided to finalize the pool of items measuring hybrid cognition of visitors only after the content analysis of subjective interviews and images captured over Instagram.

\subsection{Testing for reliability and validity}

An exploratory factor analysis with varimax rotation was deployed to assess the reliability (DeVellis, 2003 ) and construct validity (Netemeyer et al., 2003) with a convenience sample size of 140 . To assess whether a particular data set is amenable to factor analysis, examination of the strength of the relationship among the items is required (Hair et al., 2006; Bohmstedt \& Borgatta, 1981). The items having factor loadings lower than .6 or cross-loaded on more than one factor were discarded. The internal consistency and reliability were proved to be significant as Cronbach's alpha was found to be $>.7$ (Hair et al., 2006). While 15 items were significantly loaded for destination bonding, 5 items were found significant to measure e-WOM (Table-2).

\section{Table 2}

\section{EFA results}

\begin{tabular}{|c|c|c|c|c|c|}
\hline $\begin{array}{l}\text { Dimensions } \\
\text { assigned }\end{array}$ & Scale items & $\begin{array}{l}\text { Factor } \\
\text { load }\end{array}$ & Mean & SD & $\alpha$ \\
\hline \multirow{5}{*}{$\begin{array}{l}\text { Destination } \\
\text { dependence }\end{array}$} & $\begin{array}{l}\text { I could not imagine anything better than the physical backdrop and facilities provided by } \\
\text { Santiniketan to fulfill my inherent needs }\end{array}$ & .787 & 5.09 & 1.27 & \multirow{5}{*}{0.935} \\
\hline & I consider the physical backdrop and facilities provided by Santiniketan to be the best & .766 & 5.81 & 1.44 & \\
\hline & I prefer Santiniketan as destination to others for recreation/ leisure & .774 & 5.42 & 1.37 & \\
\hline & I choose Santiniketan as destination even when the alternatives are recommended to me & .733 & 5.01 & 1.29 & \\
\hline & I enjoy visiting Santiniketan more than any other destination & .776 & 5.81 & 1.65 & \\
\hline \multirow{3}{*}{$\begin{array}{l}\text { Destination } \\
\text { identity }\end{array}$} & I identify myself strongly with Santiniketan & .719 & 4.50 & 1.37 & \multirow{3}{*}{0.917} \\
\hline & I feel connected with the local culture, ethnicity and tradition of the destination & .708 & 4.33 & 1.29 & \\
\hline & Visiting Santiniketan speaks a lot about who I am & .728 & 4.89 & 1.66 & \\
\hline \multirow{5}{*}{$\begin{array}{l}\text { Affective } \\
\text { attachment }\end{array}$} & I feel attached to Santiniketan & .707 & 5.57 & 1.00 & \multirow{5}{*}{0.899} \\
\hline & I feel a strong sense of belonging to Santiniketan & .729 & 4.89 & 1.12 & \\
\hline & My personal values are reflected in Santiniketan as destination & .751 & 5.47 & 1.62 & \\
\hline & Santiniketan, as a destination, means a lot to me & .763 & 5.82 & 1.76 & \\
\hline & I have lot of fond memories of Santiniketan & .949 & 5.27 & 1.90 & \\
\hline \multirow{3}{*}{$\begin{array}{l}\text { Destination } \\
\text { social } \\
\text { bonding }\end{array}$} & Many of my relatives/friends prefer visiting Santiniketan to other destinations & .867 & 5.14 & 1.41 & \multirow{3}{*}{0.906} \\
\hline & $\begin{array}{l}\text { If I decide not to visit Santiniketan any more then I would lose contact with a number of } \\
\text { local friends and acquaintance }\end{array}$ & .820 & 5.05 & 1.29 & \\
\hline & $\begin{array}{l}\text { If I decide not to visit Santiniketan any more, my friends and acquaintance will be } \\
\text { disappointed with me }\end{array}$ & .654 & 5.37 & 1.19 & \\
\hline \multirow{5}{*}{$e-W O M$} & $\begin{array}{l}\text { I am excited to share images and texts about my experience of visiting Santiniketan with } \\
\text { online community }\end{array}$ & .717 & 5.09 & 1.23 & \multirow{5}{*}{0.925} \\
\hline & I am satisfied to post my feelings online about Santiniketan as a place of must-visit & .699 & 4.98 & 1.09 & \\
\hline & $\begin{array}{l}\text { I have interacted with my friends and relatives on social networking platforms and } \\
\text { recommended to visit Santiniketan }\end{array}$ & .701 & 4.99 & 1.48 & \\
\hline & $\begin{array}{l}\text { I shall continue to share online my positive feelings about Santiniketan as a destination } \\
\text { to visit }\end{array}$ & .698 & 4.89 & 1.11 & \\
\hline & $\begin{array}{l}\text { I have shared a lot of information electronically with the prospective visitors to } \\
\text { Santiniketan }\end{array}$ & .711 & 5.12 & 1.62 & \\
\hline
\end{tabular}

Extraction Method: Principal Component Analysis.

Rotation Method: Varimax with Kaiser Normalization.

Rotation converged in 5 iterations

KMO: .872, Bartlett test of Sphericity: Chi-square-912.118, df= 171, Sig.: .000 
EFA explained $69.26 \%$ of overall variance. Bartlett's test of Sphericity (a statistical test for the presence of correlations among the variables) and the KMO (Kaisere Meyere Olkin) measure of sampling adequacy were measured to assess the factorability of the data. The KMO value at .872 exceeds the acceptable minimum value which is .6 (Hair et al., 2006). The Barlett's test of Sphericity was found to be significant (Chi-square-912.118, $\mathrm{df}=131, .000 \mathrm{p}<.00$ ). The Cronbach's alpha score of reliability ranged from .899 to .935 . To achieve a more meaningful and interpretable solution, some items which loaded on more than one factor were deleted.

\section{Data analysis}

Demographically significant differences were not observed between genders and ages of informants, rather, length of stay, whether visited for first time and information about present location were found relevant for qualitative analysis. The researcher also, more specifically, sought to develop an understanding about the informants' psycho-physical state as 'experiential informant' (present at the destination and sharing hybrid cognition through Instagram imagery) or as 'reflective informant' (currently at his/her hometown and reminiscing memories of destination and sharing hybrid cognition through Instagram imagery). The qualitative data analysis using Instagram photos and the first part of the subjective interview content was structured as per the guidelines laid down by Kozinets (2002). The imageries were categorized for analysis based on the 'centric' theme proposed by Tussyadiah and Fesenmaier (2009) namely: (a) site-centric, (b) self-centric, (c) activity-centric and (d) other centric. The content analysis using the subjective response was done by deploying the summative approach (Hsieh and Shannon, 2005). The initial set (Fig.1a to Fig.1h) of Instagram imageries is reflective of cognitive bonding between the visitors and the destination visited (Santiniketan) on the basis of physical surroundings/ environment and amenities. The depiction of destination using Instagram imagery also justifies the visitors' opinion about destination distinctiveness whereby they have portrayed Santiniketan as a serene and rustic place with rich cultural and ethnic legacy. The summative content analysis (SCA) of subjective interviews about destination distinctiveness allowed the researcher to identify the hedonic cognition based on site-centric image displays using Instagram application. The findings are in line with the observations made by Lewicka (2011) that physical dimensions act as faster source of destination bonding compared to social dimensions.

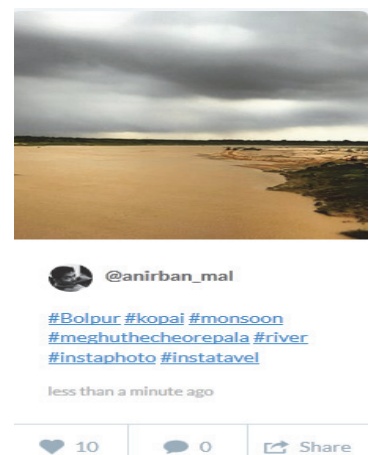

Img.1

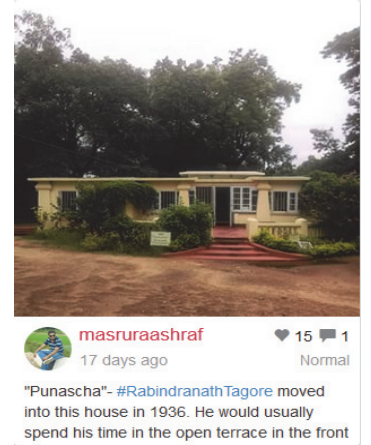

Img.5

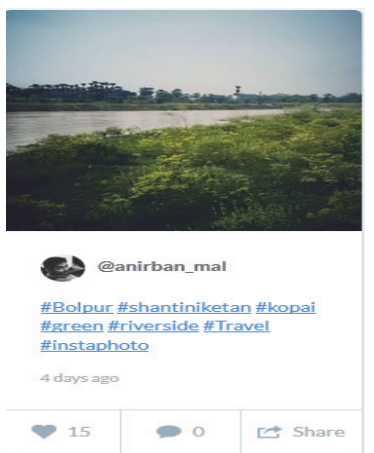

Img.2

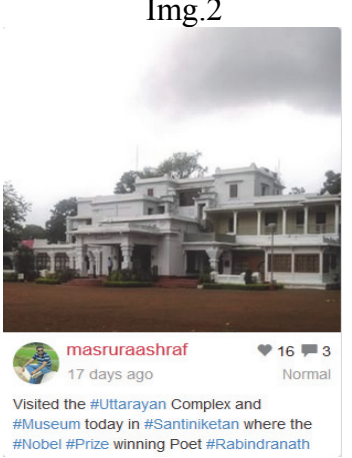

Img.6

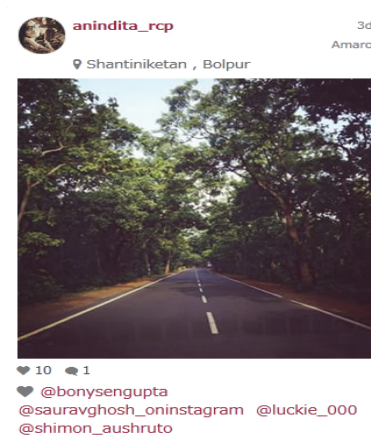

Img. 3

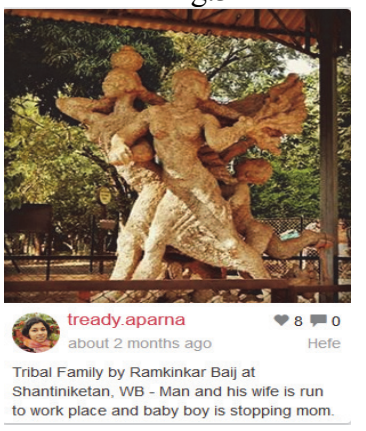

Img. 7

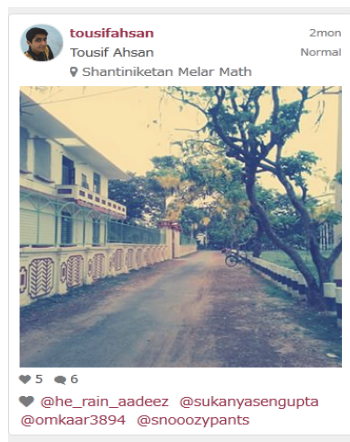

Img.4

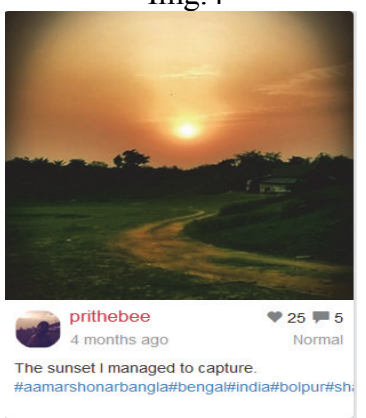

Img. 8 
The images reflecting activities involving the visitors at the destination exhibits both their destination referent and destination congruent continuities as the activity-centric images were shared via Instagram application. The visitors' participation and being witness to destination specific activities and its subsequent image displays conform to their utilitarian state of cognition. The SCA and image analysis prompted the researcher to assign this utilitarian cognition of the visitors to 'lovemark to destination' as projected by Pawle and Cooper (2006) and Roberts (2004). According to Toyama and Yamada (2012) the 'mystery' component of 'lovemark to destination' centres on experiences and discoveries related to destination which are activity specific. A vast majority of the informant shared their experiences and feelings about the cultural and ethnic practices of Santiniketan which included the internationally famous festivals namely 'Poush Mela' and 'Basantotsav'. The selective images are also reflective of the rich tradition of performing art and crafts of Santiniketan. Fig. 1i to Fig.1p represents the visual imageries of destination specific activities and experiences shared by the visitors via Instagram application:

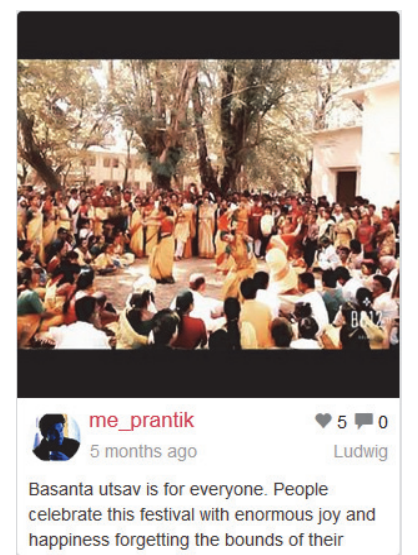

Img. 9

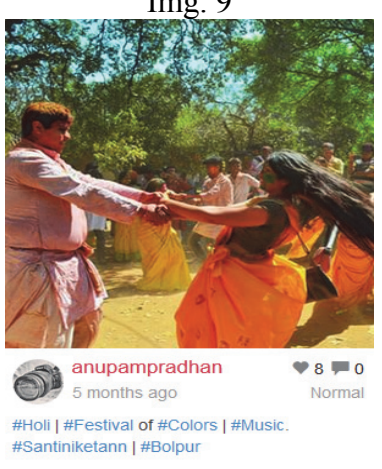

Img. 13

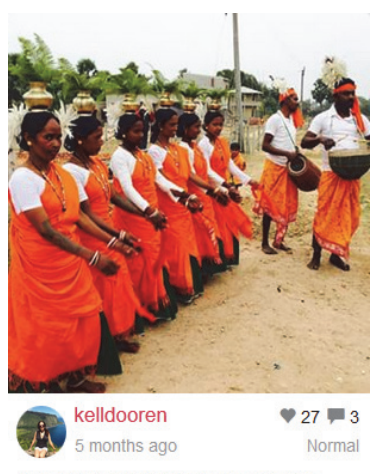

A warm welcome to the village of Bolpur, India. Can't believe it's been over a month already! \#india \#indiatrip2015 \#bolpur Img. 10

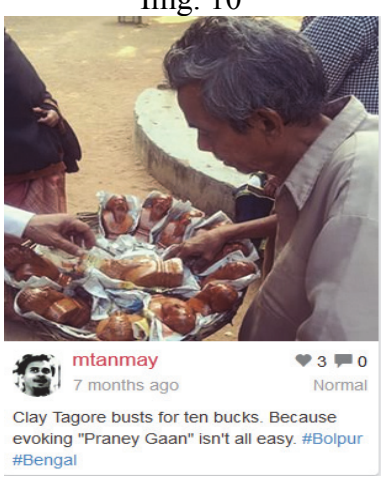

Img. 14

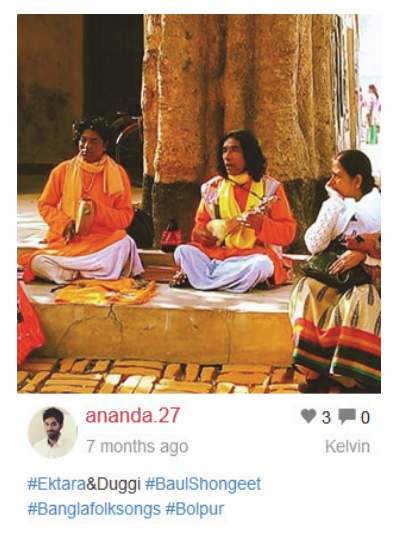

Img. 11

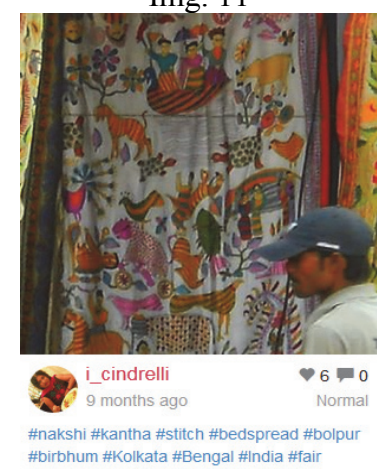

Img. 15

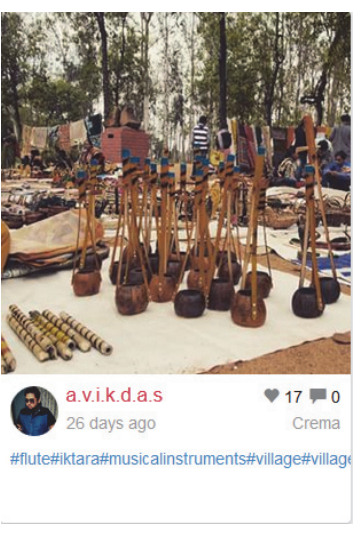

Img. 12

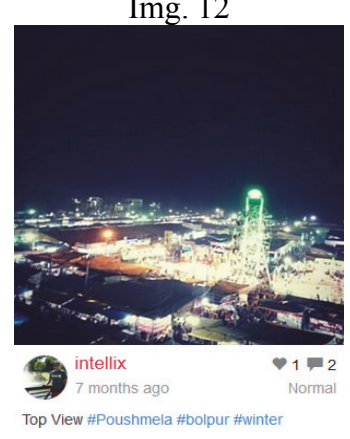

Img. 16

Self-centric activities portray the destination-related self-esteem of the visitors. The SCA and image analysis brings out the pride associated with the destination visited. In almost every image the visitors have masked their own portrait with the backdrop of the destination marking evocation of emotional values associated with the same. The 'intimacy' dimension of 'lovemark to destination' (Pawley \& Cooper, 2006) has been reflected in the images. There are also few other activities which also represent a strong undercurrent of both physical and emotional values attached to the destination by the visitors, interpreted on the basis of textual explanation of images and content analysis, to be associated with prestige and status (Fig. 17 to Fig. 32). 

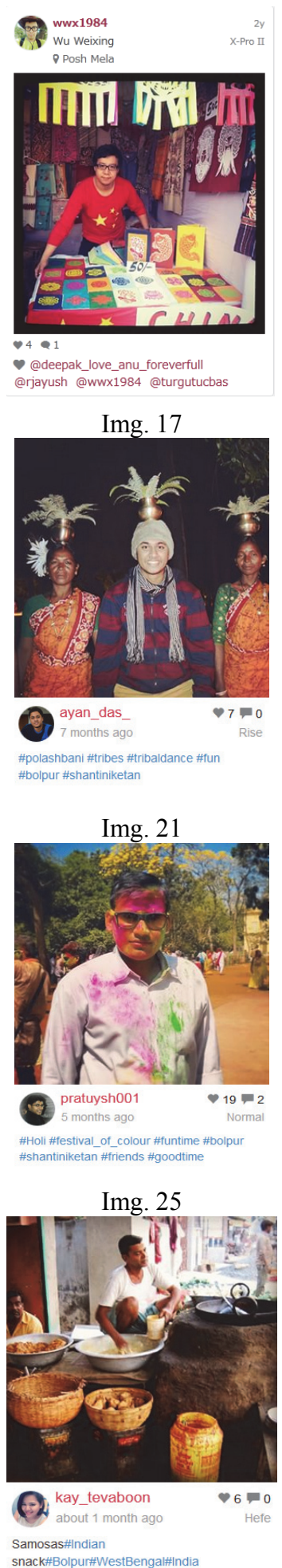

Img. 29
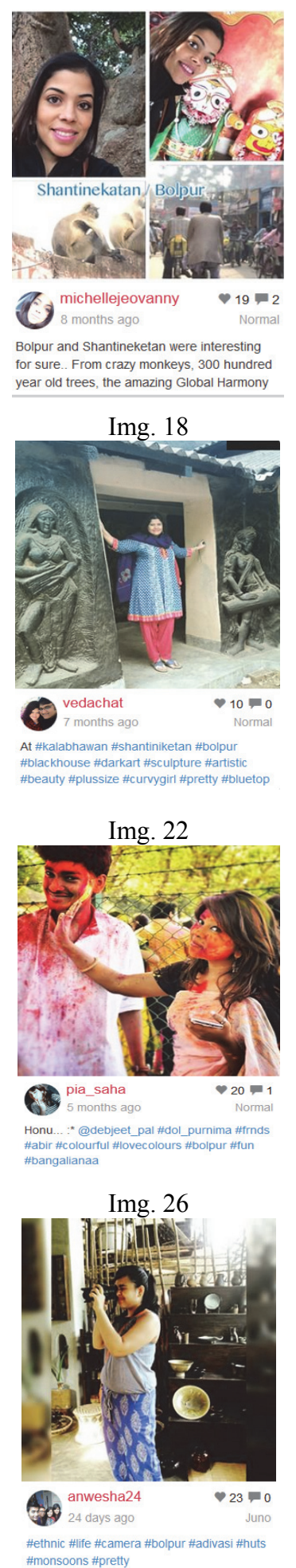

Img. 30
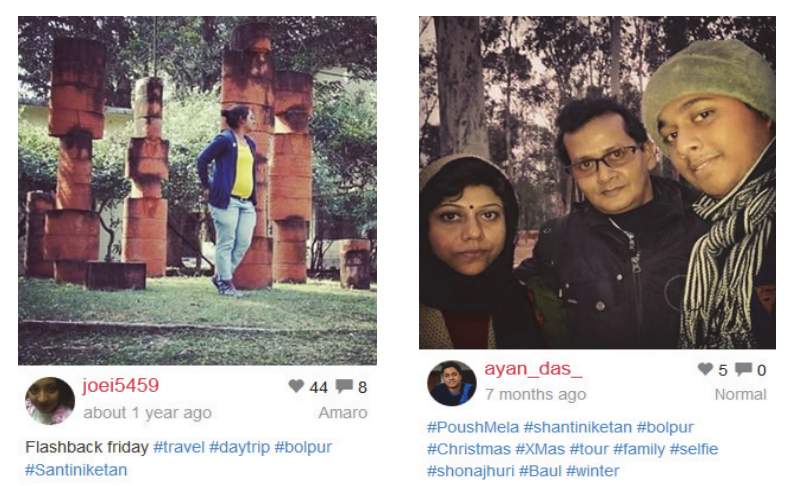

Img. 19

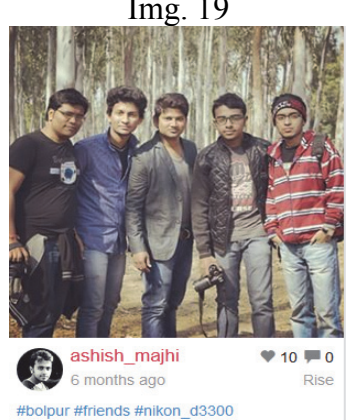

Img. 23

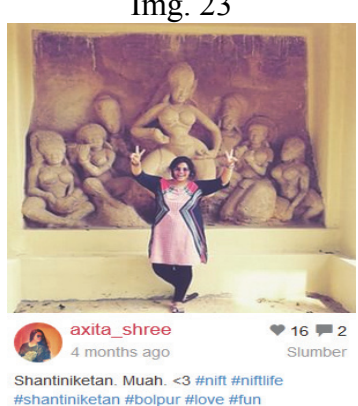

Img. 27

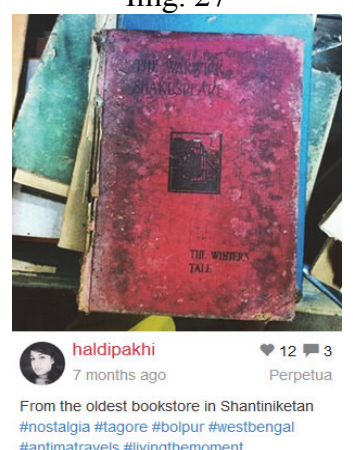

Img. 31
Img. 20

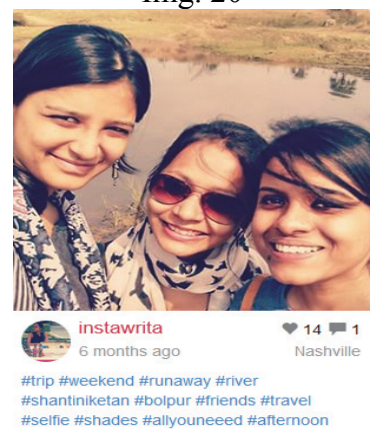

Img. 24

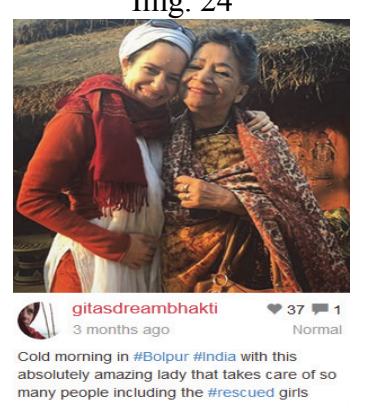

Img. 28

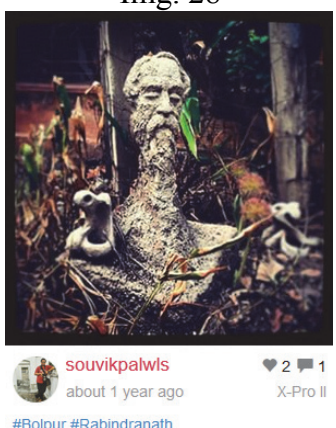

Img. 32

Analysis of subjective content have identified a stream of homogeneous expressions using common terminologies by the informants related to the destination (Santiniketan) which is a mix of their physical and emotional values derived from their visit, namely 'serene and rustic landscape', 'vibrant and rich culture', 'collection of handicraft items as souvenirs', 'interaction with local community', 'sense of pride and satisfaction associated with visiting Santiniketan', 'tranquility and solitude of the destination leading to mental calmness', 'green and pure environment', 'simplicity of life (some said 'escape from complex urban life'), 'attraction of traditional events and festivals' and 'accessibility, facilities and 
amenities related to the destination'. These mental projections can also be identified with the images captured and shared across networking platform. An initial pool of 19 items was finalized to generate response considering the hybrid components (physical and emotional values expressed via Instagram imagery) following the content (interviews and images) analysis. Exploratory factor analysis was applied to gain insights about the dimensionality (Table-3). EFA explained $71.09 \%$ of overall variance. Internal reliability was established as Cronbach's alpha (.937 and .949 for hedonic and utilitarian dimension respectively) was found significant. Bartlett's test of Sphericity and the KMO measure of sampling adequacy were also measured $(\mathrm{KMO}=.895, \mathrm{Chi}$-square $=564.761, \mathrm{df}=89, \mathrm{p}<.00$.$) and was$ found to be significant (Hair et al., 2006).

Table 3

EFA results

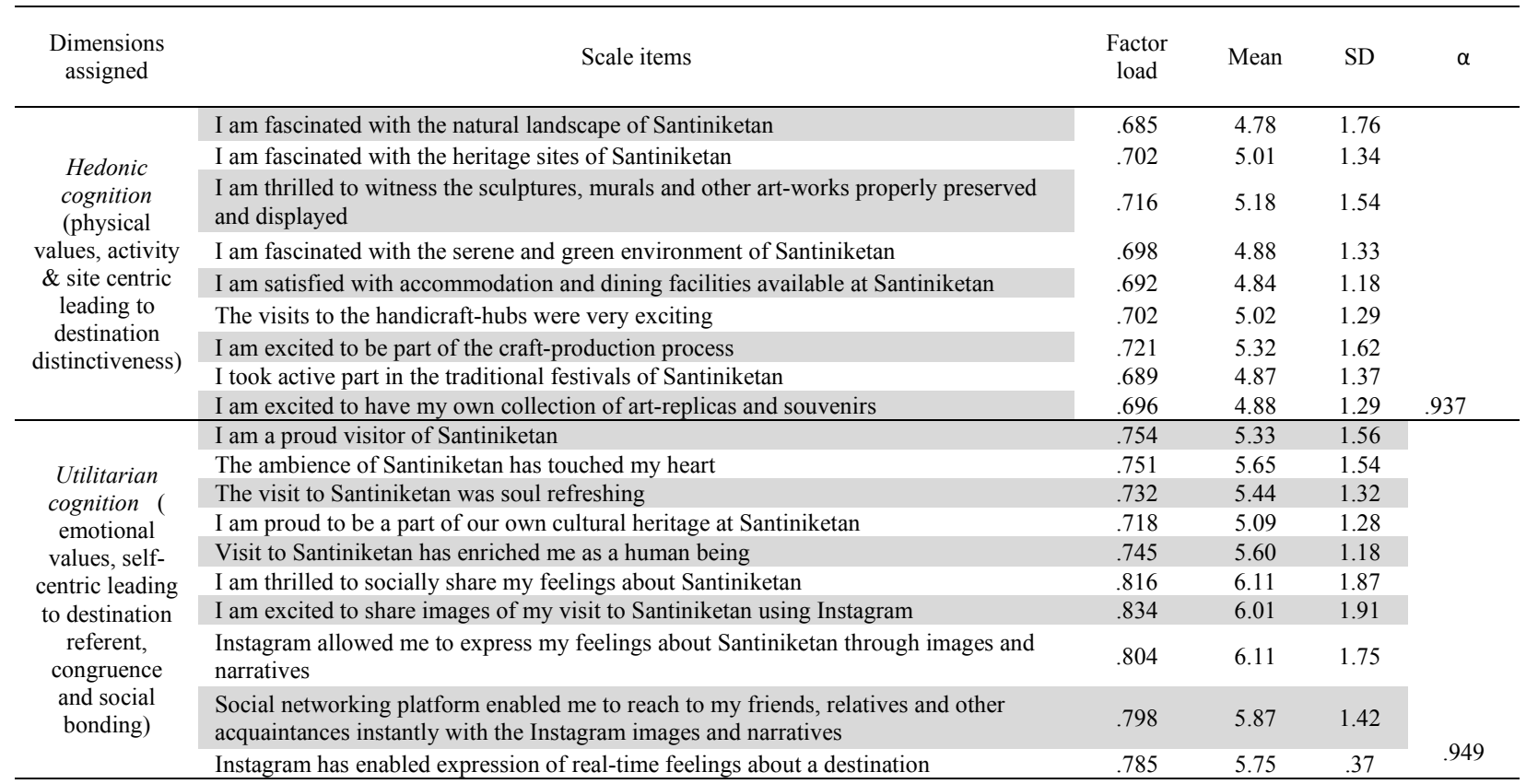

Extraction Method: Principal Component Analysis.

Rotation Method: Varimax with Kaiser Normalization.

Rotation converged in 5 iterations.

KMO: .895, Bartlett test of Sphericity: Chi-square-546.761, df=9, Sig.: .000

To examine the first hypothesis $\left(\mathrm{H}_{1}\right)$ bivariate correlation was deployed. The results of the same have been summarized in Table 4.

Table 4

Results of bivariate correlation

\begin{tabular}{|c|c|c|c|c|c|c|c|}
\hline & & HEDCOG & UTLCOG & DDP & DID & AFA & DSB \\
\hline \multirow{3}{*}{ HEDCOG } & Pearson Corr. & 1 & & & & & \\
\hline & Sig. (2-tailed) & & & & & & \\
\hline & $\mathrm{N}$ & 140 & & & & & \\
\hline \multirow{3}{*}{ UTLCOG } & Pearson Corr. & $.221^{* * *}$ & 1 & & & & \\
\hline & Sig. (2-tailed) & .000 & & & & & \\
\hline & $\mathrm{N}$ & 140 & 140 & & & & \\
\hline \multirow{3}{*}{ DDP } & Pearson Corr. & $.305^{* *}$ & $.284^{* *}$ & 1 & & & \\
\hline & Sig. (2-tailed) & .000 & .000 & & & & \\
\hline & $\mathrm{N}$ & 140 & 140 & 140 & & & \\
\hline \multirow{3}{*}{ DID } & Pearson Corr. & $.151^{*}$ & $.339^{* *}$ & $.117^{*}$ & 1 & & \\
\hline & Sig. (2-tailed) & .002 & .000 & .004 & & & \\
\hline & $\mathrm{N}$ & 140 & 140 & 140 & 140 & & \\
\hline \multirow{3}{*}{ AFA } & Pearson Corr. & $.199^{* *}$ & $.274^{* * *}$ & $.201^{* *}$ & .097 & 1 & \\
\hline & Sig. (2-tailed) & .000 & .000 & .000 & .092 & & \\
\hline & $\mathrm{N}$ & 140 & 140 & 140 & 140 & 140 & \\
\hline \multirow{3}{*}{ DSB } & Pearson Corr. & $.201^{* * *}$ & $.425^{* *}$ & .044 & $.298^{* * *}$ & $.147^{*}$ & 1 \\
\hline & Sig. (2-tailed) & .000 & .000 & .532 & .000 & .003 & \\
\hline & & 140 & 140 & 140 & 140 & 140 & 140 \\
\hline
\end{tabular}

**Correlation is significant at the 0.01 level (2-tailed).

* Correlation is significant at the 0.05 level (2-tailed).

HEDCOG- hedonic cognition, UTLCOG- utilitarian cognition, DDP-destination dependence, DID- destination identity, AFA- affective attachment, 
The results confirmed existence of moderate to strong dimensional correlation between destination bonding and hybrid cognition. While hedonic cognition shared strong correlation with destination dependence $\left(\mathrm{r}=.305^{* *}, \mathrm{p}<.001\right)$, affective attachment $(\mathrm{r}=.199 * *, \mathrm{p}<.005)$ and destination social bonding $\left(\mathrm{r}=.201^{* *}, \mathrm{p}<.005\right)$, it represented moderate correlation with destination identity $\left(\mathrm{r}=.151^{* *}\right.$, $\mathrm{p}<.005)$. On the other hand utilitarian cognition exhibited strong correlationship with all dimensional constructs of destination bonding, namely destination dependence $\left(\mathrm{r}=.284^{* *}, \mathrm{p}<.001\right)$, destination identity $\left(\mathrm{r}=.339^{* *}, \mathrm{p}<.001\right)$, affective attachment $\left(\mathrm{r}=.274^{* *}, \mathrm{p}<.001\right)$ and destination social bonding $\left(\mathrm{r}=.425^{* *}, \mathrm{p}<.005\right)$. Analysis provided partial support to $\mathrm{H}_{1}$. The researcher deployed two sets of hierarchical multiple regression analysis (HMRA) to understand the moderating effects of hybrid cognition (HYBCOG) on the relationship between destination bonding (DBond) and e-WOM. The results of the HMRA were tabulated in Tabe 5, Table 6 and Table 7.

Table 5

Model Summary

\begin{tabular}{|c|c|c|c|c|c|c|c|c|c|}
\hline \multirow{2}{*}{ Model } & \multirow{2}{*}{$\mathrm{R}$} & \multirow{2}{*}{ R Square } & \multirow{2}{*}{$\begin{array}{l}\text { Adjusted R } \\
\text { Square }\end{array}$} & \multirow{2}{*}{$\begin{array}{l}\text { Std. Error of the } \\
\text { Estimate }\end{array}$} & \multicolumn{5}{|c|}{ Change Statistics } \\
\hline & & & & & R Square Change & F Change & df1 & $\mathrm{df} 2$ & Sig. F Change \\
\hline 1 & $.469^{\mathrm{a}}$ & .219 & .217 & .35267 & .219 & 173.372 & 1 & 138 & .000 \\
\hline 2 & $.440^{\mathrm{b}}$ & .193 & .191 & .33897 & .026 & 20.652 & 1 & 136 & .000 \\
\hline
\end{tabular}

a. Predictors: (Constant), DBond

b. Predictors: (Constant), DBond, HYBCOG

c. Dependent Variable: e-WOM

Table 7

ANOVA

\begin{tabular}{|c|c|c|c|c|c|c|}
\hline & Model & Sum of Squares & df & Mean Square & $\mathrm{F}$ & Sig. \\
\hline \multirow{3}{*}{1} & Regression & 47.060 & 1 & 47.060 & 173.372 & $.000^{\mathrm{b}}$ \\
\hline & Residual & 128.112 & 138 & .180 & & \\
\hline & Total & 175.171 & 136 & & & \\
\hline \multirow{3}{*}{2} & Regression & 51.060 & 2 & 25.530 & 102.448 & $.000^{c}$ \\
\hline & Residual & 124.111 & 135 & .175 & & \\
\hline & Total & 175.171 & 133 & & & \\
\hline
\end{tabular}

Dependent Variable: e-WOM

b. Predictors: (Constant), DBond

c. Predictors: (Constant), DBond, HYBCOG

Table 8

Coefficient $^{\mathrm{a}}$

\begin{tabular}{|c|c|c|c|c|c|c|}
\hline & \multirow{2}{*}{ Model } & \multicolumn{2}{|c|}{ Unstandardized Coefficients } & \multirow{2}{*}{$\frac{\text { Standardized Coeff. }}{\text { Beta }}$} & \multirow[b]{2}{*}{$\mathrm{t}$} & \multirow{2}{*}{ Sig. } \\
\hline & & $\mathrm{B}$ & Std. Error & & & \\
\hline \multirow{3}{*}{1} & (Constant) & 2.117 & .125 & & 23.175 & .000 \\
\hline & DBond & .354 & .024 & .379 & 16.150 & .000 \\
\hline & (Constant) & 3.523 & .129 & & 23.888 & .000 \\
\hline \multirow[t]{2}{*}{2} & DBond & 417 & .024 & .487 & 16.608 & .000 \\
\hline & HYBCOG & .060 & .013 & .149 & 6.233 & .000 \\
\hline
\end{tabular}

a. Dependent Variable: e-WOM

Model-1 is significant without interaction term. $\mathrm{F}(1,138)=173.372, \mathrm{p}<.001$

Model-2 is significant with interaction term. $\mathrm{F}(2,136)=102.448, \mathrm{p}<.001$

Model-2 accounted for significantly more variance than Model-1. Model-2 with the interaction effect of DBond and HYBCOG accounted for significantly more variance than DBond as a standalone variable. $\mathrm{R}^{2}$ change $=.026, \mathrm{p}=.000$, indicated that there is potentially significant and positive moderation of hybrid cognition on the relationship between destination bonding e-WOM. The interaction term between DBond and HYBCOG was added to the regression model, which accounted for a significant proportion of the variance in visitors' e-WOM, $\Delta \mathrm{R}^{2}=.026, \Delta \mathrm{F}(1,138)=20.652, \mathrm{p}=$ $.000, \beta=.149, \mathrm{t}=6.233, \mathrm{p}<.01$. Since we have received potentially significant and positive moderating effects, we decided to run regression on centered terms to examine the effect. To avoid potentially problematic high multicollinearity with the interaction term, the variables were centered and an 
interaction term between DBond and HYBCOG was created (Aiken \& West, 1991). To assess the effects we deploy the 'PROCESS by Andrew F. Hayes' in SPSS package. The results are as follows:

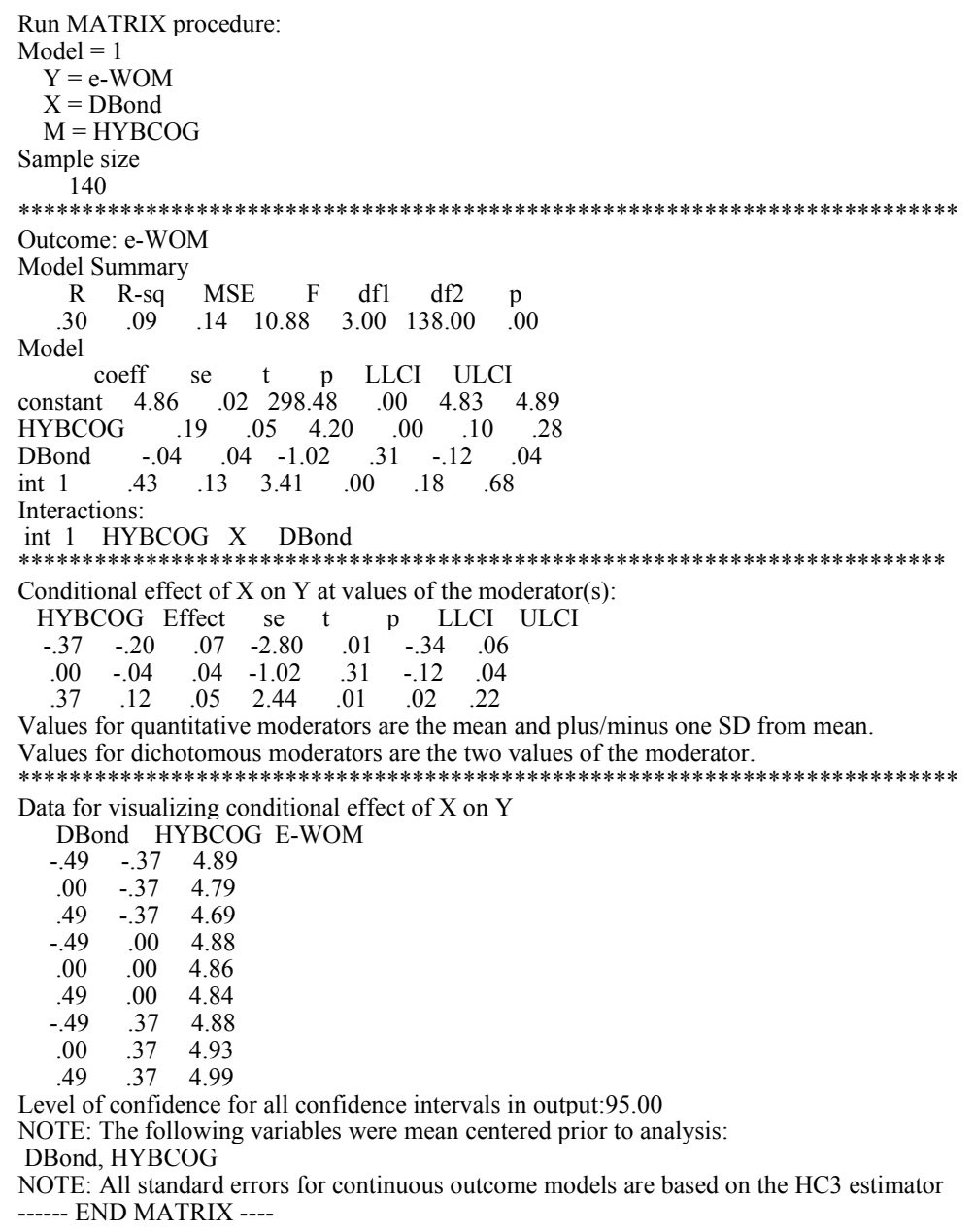

Examination of the interaction plot revealed an enhancing effect that elevated level of hybrid cognition will increase the impact of destination bonding on e-WOM. Structural equation modeling was applied to estimate the confirmatory factor analysis (CFA) models related to the proposed conceptual model. A number of goodness-of-fit statistics were obtained. The GFI (0.984) and AGFI (0.979) scores (Table 9) for all the constructs were found to be $>.900$ indicating a good fit has been achieved (Hair et al, 1998). The CFI (0.962) and RMSEA (0.057) confirmed adequate model fit as per Bentler, 1992. The Chi-square $\left(\chi^{2}=784.16, \mathrm{df}=376, \mathrm{p}=0.000\right)$ is significant at $\mathrm{p}<0.001$.

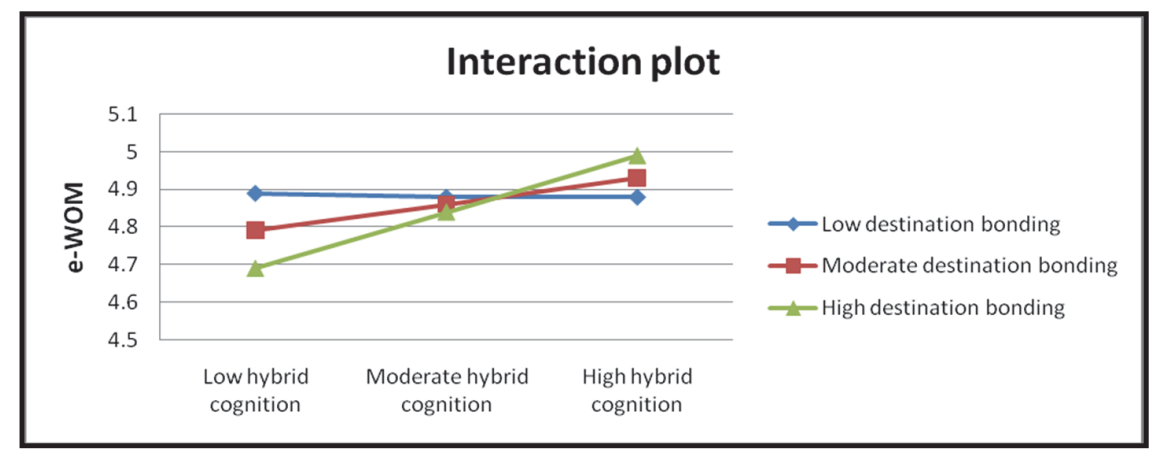


Table 9

Goodness-of-fit indices

\begin{tabular}{ccccccccc}
\hline Fit indices & $\chi^{2}$ & df & P & GFI & AGFI & CFI & RMR & RMSEA \\
\hline Values & 784.16 & 376 & 0.000 & 0.984 & 0.979 & 0.962 & 0.045 & 0.057 \\
\hline
\end{tabular}

The final structural model with regression coefficients is depicted in Fig.3

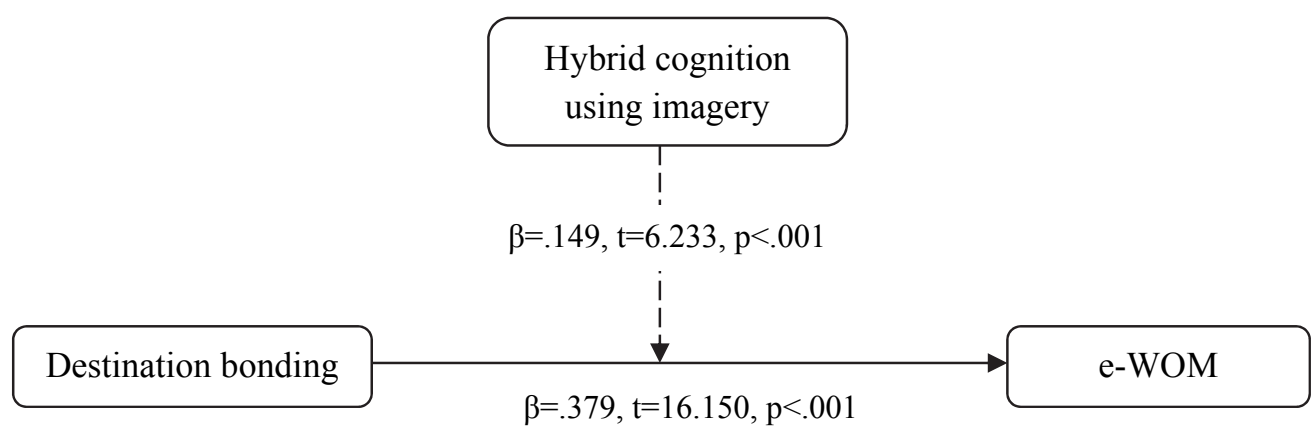

Fig. 3. Final structural model

\section{Discussion and conclusion}

The study focused on assessing the implications of sharing electronic images in the context of destination bonding and its subsequent impact on e-WOM. Literature revealed that both geo-physical and cultural highlights have antecedent effects on destination bonding which, in turn, stimulates prodestination advocacy. But with the changing pattern of communication and interaction triggered by mobile devices and online sharing platforms, the nature of cognitive expression as a precursor to destination bonding has undergone a serious metamorphosis. The study reinforced researcher's postulate as sharing of visual imagery and supportive text was found as a strong and enhanced manifestation of utilitarian value which, at the same time, has been reflective of hedonic feelings associated with the destination. The study further identified a technology-induced fused cognition, termed as 'hybrid cognition' that has a strong and positive dimensional impact on destination bonding. It was significantly detected in the use of Instagram images across social networking sites namely Facebook. The study identified the underlying notions of hybrid cognition namely destination distinctiveness (related to destination identification), destination referent continuity (legacy of visits to a specific destination as a habitual coherent reference), destination congruence (reflection of selfimage) and destination-related self-esteem (taking pride in visiting specific destination). The study threw light on assimilation of these notions and expression through Instagram imagery and narratives. The summative content analysis was reflective of these notions. While assessing the impact of moderation of hybrid cognition on the link between destination bonding and e-WOM, it was found that strong and positive hybrid cognition increases the impact of destination bonding on the tendency of eWOM, where, technologically, e-WOM uses the service of Instagram and online platforms of information sharing. The study also identified that e-WOM is an expression of visuals and narratives captured by mobile devices, namely, Instagram and shared across social networking platforms for maximum reach and impact. Santiniketan was selected as the destination for the purpose of this study as it has been recognized to host perennial flow of visitors who flock to experience its rich culture, tradition and heritage. The study reinforced the common assumption that a visit to Santiniketan is not only visiting a specific destination, but also reflects visitors' choice of destination, thereby, is reflective of the feeling of 'destination related self-esteem'.

With the advent and proliferation of social media and supportive technology to share images and narratives, the online community has grown in stature as a source of reference. Considering that eWOM is anonymous and has global spread in real-time, destination marketing organizations (DMOs) 
are acknowledging it having stronger impact on decision making compared to conventional word-ofmouth. The social presence induced by e-WOM as output behavior of hybrid cognition leading to destination bonding should be seriously considered by the DMOs to understand traveler behavior. Extensive study of images and narratives shared by the visitors as an expression of destination bonding could be extremely useful to DMOs to identify elements to differentiate and highlight travel offers.

This study has certain geo-physical limitations as it was confound to a single location with small sample size as informant. The study can be taken up for a wider geographical coverage with large sample to have a more generalized model. Future extrapolations of the study can be done by incorporating a number of relevant marketing and travelling issues namely travel customization, destination branding, destination communication etc. Consequently new relationship may be identified involving studies related to destination bonding and new marketing paradigms focused on travelling and travel behaviors.

\section{References}

Albert, N., \& Merunka, D. (2013). The role of brand love in consumer-brand relationships. Journal of Consumer Marketing, 30(3), 258-266.

Amsden, B. L., Stedman, R. C., \& Kruger, L. E. (2010). The creation and maintenance of sense of place in a tourism-dependent community. Leisure Sciences, 33(1), 32-51.

Bentler, P. M. (1992). On the fit of models to covariances and methodology to the Bulletin.. Psychological bulletin, 112(3), 400.

Blackshaw, P., \& Nazzaro, M. (2006). Consumer-generated media (CGM) 101: Word-of-mouth in the age of the web-fortified consumer. New York: Nielsen BuzzMetrics.

Bohmstedt, G., \& Borgatta, E. (1981). Social measurement: Current issues. Beverly Hills, CA: Sage.

Bowen, \& Clarke (2009). Contemporary tourist behaviour: Yourself and others as tourists. Wallingford, UK: CABI Publishing.

Boley, B. B., Magnini, V. P., \& Tuten, T. L. (2013). Social media picture posting and souvenir purchasing behavior: Some initial findings. Tourism Management, 37, 27-30.

Brocato, E. D. (2007). Place attachment: an investigation of environments and outcomes in a service context.

Bronner, F., \& de Hoog, R. (2010). Vacationers and eWOM: Who posts, and why, where, and what?. Journal of Travel Research.

Brown, G., Raymond, C. M., \& Corcoran, J. (2015). Mapping and measuring place attachment. Applied Geography, 57, 42-53.

Criswell, J., \& Canty, N. (2014). Deconstructing Social Media: An Analysis of Twitter and Facebook Use in the Publishing Industry. Publishing Research Quarterly, 30(4), 352-376.

del Bosque, I. R., \& San Martin, H. (2008). Tourist satisfaction a cognitive-affective model. Annals of tourism research, 35(2), 551-573.

DeVellis, R. F. (2012). Scale development: Theory and applications (Vol. 26). Sage publications.

Dippelreiter, B., Grün, C., Pöttler, M., Seidel, I., Berger, H., Dittenbach, M., \& Pesenhofer, A. (2008). Online tourism communities on the path to Web 2.0: an evaluation. Information technology \& tourism, 10(4), 329353.

Fullilove, M. T. (1996). Psychiatric implications of displacement: contributions from the psychology of place. American Journal of Psychiatry 153(12), 1516-1523.

Greider, T., \& Garkovich, L. (1994). Landscapes: The social construction of nature and the environment. Rural sociology, 59(1), 1-24.

Hair, J., Black, B., Babin, R., Anderson, R., and Tatham, R. (2006). Multivariate data analysis (6th ed.). New York: Prentice Hall.

Hair, J.F., Anderson, R.E., Tatham, R.L. \& Black, W.C. (1998). Multivariate data analysis. $5^{\text {th }}$ edition, Prentice Hall, Upper Saddle, New jersey.

Halpenny, E. A. (2010). Pro-environmental behaviours and park visitors: The effect of place attachment. Journal of Environmental Psychology, 30(4), 409-421.

Halpenny, E.A. (2006). Environmental behaviour, place attachment and park visitation: A case study of visitors to Point Pele National Park, Doctoral Thesis, University of Waterloo. Retrieved from http://www.etd.uwaterloo.ca/etd/eahalpen2006.pdf

Hammit, W.E., Backlund, E.A. \& Bixler, R.D. (2006). Place bonding for recreational places: Conceptual and empirical development. Leisure Studies, 25(1), 71-41. 
Hammock, G. \& Richardson, D. S. (2011). Love attitudes and relationship experience. The Journal of Social Psychology, 151(1), 608-624.

Hanan, H. \& Putit, N. (2014). Express marketing of tourism destination using Instagram in social media networking. Hospitality and Tourism: Synergizing Creativity and Innovation in Research, CRC Press, 471474. Hernandez, B., Hidalgo, M.C., Salazar-Laplace, M.E. \& Hess, S. (2007). Place attachment and place identity in natives and non-natives. Journal of Environment Psychology, 27, 310-319. doi:10.1016/j.jenvp.2007.06.003

Hinds, J. \& Sparks, P. (2008). Engaging with natural environment: The role of affective connection and identity. Journal of Environmental Psychology, 28, 109-120.

Hochman, N. \& Schwartz, R. (2012). Visualizing Instagram: Tracing cultural visual rhythms. Association for the Advancement of Artificial Intelligence. In Proceedings of $6^{\text {th }} 11$ AAAI Conference on Weblogs and Social Media.

Hsieh, H. F., \& Shannon, S. E. (2005). Three approaches to qualitative content analysis. Qualitative Health Research, 15(9), 1277-1288.

Kals, E., Shumaker, D. \& Montada, L. (1999). Emotional affinity toward nature as a motivational basis to protect nature. Environment and Behaviour, 31(2), 178-202.

Kaplan, A. M. \& Haenlein, M. (2010). Users of the world, unite! The challenges and opportunities of Social Media. Business Horizons, 53(1), 59-68.

Knez, L. (2005). Attachment and identity as related to a place and its perceived climate. Journal of Environmental Psychology, 25, 207-218.

Kozinets, R. (2002). The field behind the screen: Using Netnography for marketing research in online communities. Journal of Marketing Research, 39(1), 61-72.

Kruger, M. \& Saayman, M. (2010). Travel Motivation of Tourists to Kruger and Tsitsikamma National Parks: A Comparative Study. South African Journal of Wildlife Research, 40(1), 93-102.

Kyle, G., Graefe, A. and Manning, R. (2005). Testing the dimensionality of place attachment in recreational settings. Environment and Behaviour, 37, 285-303.

Kyle, G.T., Graefe, A.R., Manning, R. \& Bacon, J. (2004). Predictors of behavioural loyalty among hikers along the Appalachain Trail. Leisure Sciences, 26(1), 99-118.

Lee, J. J., Kyle, G. \& Scott, D. (2012). Mediating effect of place attachment on the relationship between festival satisfaction and loyalty to the festival hosting destination. Journal of Travel Research, 51(6), 754-767.

Lee, T. H. (2011). How recreation involvement, place attachment and conservation commitment affect environmentally responsible behaviour. Journal of Sustainable Tourism, 19(7), 895-915.

Lee, J., Graefe, A.R. \& Burns, R.C. (2007). Examining the antecedents of destination loyalty in a forest setting. Leisure Science, 29, 463-481.

Lewicka, M. (2011). Place attachment: How far have we come in the last 40 years? . Journal of Environmental Psychology, 31, 207-230.

Line, N. \& Costen, W. (2011). Environmental attitudes, motivation and attachment: Toward a model of naturebased tourism. Proceedings of ICHRIE.

Lin, K., \& Lu, H. (2011). Why people use social networking sites: An empirical study integrating network externalities and motivation theory. Computers in Human Behavior, 27, 1152-116.

Loureiro, S. M. C., Ruediger, K. H. \& Demetris, V. (2012). Brand emotional connection and loyalty. Journal of Brand Management, 20(1), 13-27.

Mangold, W.G. \& Fauld, D.V. (2009). Social media: The new hybrid element of promotion mix. Business Horizons, 52, 357-365.

Marles, K \& Watkins, M 2003. Place attachment in tourism. Paper presented to Council of Australian Universities Tourism and Hospitality Education (CAUTHE) 2003, Canberra, Australia.

Netemeyer, R. G., Bearden, W. O. \& Sharma, S. (2003). Scaling procedures: Issues and applications. London: Sage Publications.

Parra-López, E., Bulchand-Gidumal, J., Gutiérrez-Taño, D., \& Díaz-Armas, R. (2011). Intentions to use social media in organizing and taking vacation trips. Computers in Human Behavior, 27(2), 640-654.

Pawle, J. \& Cooper, P. (2006). Measuring emotion-lovemarks: The future beyond brands. Journal of Advertising Research, 46(1), 38-48.

Pearce, P. L. \& Lee, U. (2005). Developing the travel career approach to motivation. Journal of Travel Research, 43(3), 226-237.

Prayag, G. \& Ryan, C. (2012). Antecedents of tourists' loyalty to Mauritius: The role and influence of destination image, place attachment, personal involvement and satisfaction. Journal of Travel Research, 51(3), 342-356. 
Raymond, C.M., Brown, G. \& Weber, D. (2011). The measurement of place attachment: Personal, community and environmental connections. Journal of Environmental Psychology, 30, 422-434.

Ramkissoon, H., Smith, L. D. G. \& Weiler, B. (2013). Testing the dimensionality of place attachment and its relationships with place satisfaction and pro-environmental behaviours: a structural equation modelling approach. Tourism management, 36, 552-566.

Ramkissoon, H., Weiler, B. \& Smith, L. D. G. (2012). Place attachment and pro-environmental behaviour in national parks: the development of a conceptual framework. Journal of Sustainable Tourism, 20(2), 257-276.

Rashtchy,F., Kessler, A. M., Bieber,P. J., Shindler, N. H., \& Tzeng,J. C. (2007). The user revolution: The new advertising ecosystem and the rise of the internet as a mass medium. Minneapolis, MN: Piper Jaffray Investment Research

Riley, R. B. (1992). Attachment to the ordinary landscape, in I. Altman \& S. Low (Eds.), Place attachment. New York: Plenum Press, 13-35.

Roberts, K. (2004). Lovemarks: The future beyond brands. New York: Powerhouse Books.

San Martín, H. and Rodríguez, J.I. (2008). Exploring the cognitive - affective nature of destination image and the role of psychological factors in its formation. Tourism Management, 29(2), 263-277.

Sayers, J. \& Monin, N. (2007). Love: A critical reading of lovemarks. Journal of Organizational Change Management, 20(5), 671-684.

Scannell, L. \& Gifford, R. (2010). Defining place attachment: a tripartite organizing framework. Journal of Environmental Psychology 30, 1-10.

Su, M. M., Long, Y., Wall, G. \& Jin, M. (2014).Tourist-community interactions in ethnic tourism: Tuva villages, Kanas Scenic Area, China. Journal of Tourism and Cultural Change, 12(3), 1-26.

Toyama, M. \& Yamada, Y. (2012). The relationships among tourist novelty, familiarity, satisfaction and destination loyalty: Beyond the novelty-familiarity continuum. International Journal of Marketing Studies, 4(6), 10-18.

Trauer, B. \& Ryan, C. (2004). Destination image, romance and place experience - an application of intimacy theory in tourism. Tourism Management, 26, 481-491.

Tuan, Y. F. (1974). Topophillia: a study of environmental perception, attitudes, and values. Englewood Cliffs, NJ: Prentice-Hall.

Tussyadiah, I.P. \& Fesenmaier, D.R. (2009). Mediating tourist experiences access to places via shared videos. Annals of Tourism Research, 36(1), 24-40.

Vaske, J. J. \& Kobrin, K. C. (2001). Place attachment and environmentally responsible behavior. The Journal of Environmental Education, 32(4), 16-21.

Vollmer, C. \& Precourt, G. (2008). Always on: Advertising, marketing and media in an era of consumer control. New York: McGraw-Hill.

Volo, S. (2010). Bloggers' reported tourist experiences: Their utility as a tourism data source and their effect on prospective tourists. Journal of Vacation Marketing, 16(4), 297-311.

Xiang, Z. \& Gretzel, U. (2010). Role of social media in online travel information search. Tourism Management, 31(2), 179-188.

Xiang, Z. \& Pan, B. (2011). Travel queries on cities in the United States: Implications for search engine marketing for tourist destinations. Tourism Management, 32(1), 88-97.

Yuksel, A., Yuksel, F. \& Bilim, Y. (2010). Destination attachment: Effects on Customer satisfaction and cognitive, affective and conative loyalty. Tourism Management, 31(2), 274-84.

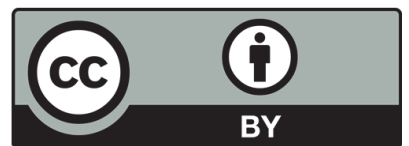

(C) 2016 by the authors; licensee Growing Science, Canada. This is an open access article distributed under the terms and conditions of the Creative Commons Attribution (CC-BY) license (http://creativecommons.org/licenses/by/4.0/). 